The INL is a

U.S. Department of Energy

National Laboratory

operated by

Battelle Energy Alliance

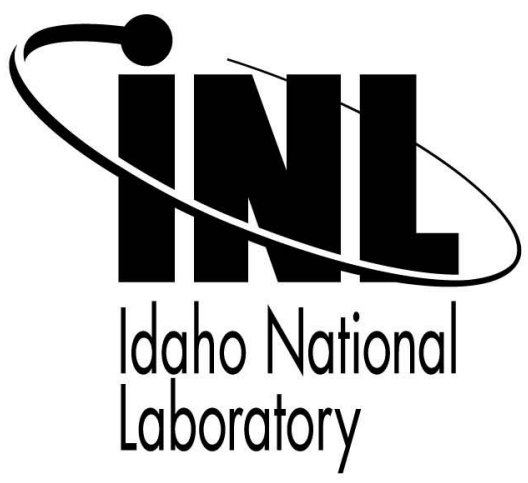

\title{
Economic Analysis of a
}

Nuclear Reactor Powered High-Temperature Electrolysis Hydrogen Production Plant

\section{$2^{\text {nd }}$ International Conference on Energy Sustainability 2008}

E. A. Harvego

M. G. McKellar

M. S. Sohal

J. E. O'Brien

J. S. Herring

\section{August 2008}

This is a preprint of a paper intended for publication in a journal or proceedings. Since changes may be made before publication, this preprint should not be cited or reproduced without permission of the author. This document was prepared as an account of work sponsored by an agency of the United States Government. Neither the United States Government nor any agency thereof, or any of their employees, makes any warranty, expressed or implied, or assumes any legal liability or responsibility for any third party's use, or the results of such use, of any information, apparatus, product or process disclosed in this report, or represents that its use by such third party would not infringe privately owned rights. The views expressed in this paper are not necessarily those of the United States Government or the sponsoring agency. 


\title{
ECONOMIC ANALYSIS OF A NUCLEAR REACTOR POWERED HIGH-TEMPERATURE ELECTROLYSIS HYDROGEN PRODUCTION PLANT
}

\author{
E. A. Harvego, M. G. McKellar, M. S. Sohal, J. E. O’Brien, J. S. Herring \\ Idaho National Laboratory \\ Idaho Falls, ID 38415, USA
}

\begin{abstract}
A reference design for a commercial-scale hightemperature electrolysis (HTE) plant for hydrogen production was developed to provide a basis for comparing the HTE concept with other hydrogen production concepts. The reference plant design is driven by a high-temperature helium-cooled nuclear reactor coupled to a direct Brayton power cycle. The reference design reactor power is 600 $\mathrm{MW}_{\mathrm{t}}$, with a primary system pressure of $7.0 \mathrm{MPa}$, and reactor inlet and outlet fluid temperatures of $540^{\circ} \mathrm{C}$ and $900^{\circ} \mathrm{C}$, respectively. The electrolysis unit used to produce hydrogen includes 4,009,177 cells with a per-cell active area of 225 $\mathrm{cm}^{2}$. The optimized design for the reference hydrogen production plant operates at a system pressure of 5.0 MPa, and utilizes an air-sweep system to remove the excess oxygen that is evolved on the anode (oxygen) side of the electrolyzer. The inlet air for the air-sweep system is compressed to the system operating pressure of $5.0 \mathrm{MPa}$ in a four-stage compressor with intercooling. The alternating-current (AC) to direct-current (DC) conversion efficiency is $96 \%$. The overall system thermal-to-hydrogen production efficiency (based on the lower heating value of the produced hydrogen) is $47.1 \%$ at a hydrogen production rate of $2.356 \mathrm{~kg} / \mathrm{s}$.

An economic analysis of this plant was performed using the standardized H2A Analysis Methodology developed by the Department of Energy (DOE) Hydrogen Program, and using realistic financial and cost estimating assumptions. The results of the economic analysis demonstrated that the HTE hydrogen production plant driven by a high-temperature helium-cooled nuclear power plant can deliver hydrogen at a competitive cost. A cost of $\$ 3.23 / \mathrm{kg}$ of hydrogen was calculated assuming an internal rate of return of $10 \%$.
\end{abstract}

\section{INTRODUCTION}

The United States is exploring the feasibility of a hydrogen-based economy with the goals of reduced oil consumption, independence from foreign energy, and reduced greenhouse gas emissions. The Idaho National Laboratory
(INL) has an on-going project funded by the Department of Energy (DOE) under the Nuclear Hydrogen Initiative studying nuclear-powered high-temperature electrolysis of steam using solid-oxide cells for large-scale hydrogen production [1-4].

Because high temperature electrolysis is an evolving technology, a reliable cost estimate for the INL high temperature electrolysis design was needed to compare it with the cost of other concepts, already developed or under development. A few researchers and organizations have developed methodologies and cost analyses for specific designs of their chosen application. Ivy [5] has provided a summary of hydrogen production costs by various companies for production rates ranging from 200-1000 kg/year to $\sim 100,000 \mathrm{~kg} /$ year. The systems were based on low temperature electrolysis using either potassium hydroxide or proton exchange membrane (PEM) electrolyzers. Estimated costs, shown in Figure 1, were $\$ 4.15 / \mathrm{kg}$ for a large system $(\sim 1000 \mathrm{~kg} /$ day $), \$ 8.09 / \mathrm{kg}$ for a medium system $(\sim 100$ $\mathrm{kg} /$ day $)$, and $\$ 19.01 / \mathrm{kg}$ for a small system $(\sim 20 \mathrm{~kg} / \mathrm{day})$, respectively. These costs were based on an assumed plant lifetime of 40 years and electrolyzer cell stack lifetimes of 515 years.

Hitachi of Japan, see Karasawa [6], also calculated the cost of producing centralized hydrogen by both the thermochemical sulfur-iodine (S.-I.) and electrolysis methods. Hitachi considered the steam-methane reforming process for producing hydrogen as a cost target. The total cost included costs for production, delivery, and distribution. Each cost consists of a fixed cost and a variable cost. The fixed cost was calculated by multiplying the capital cost by a capital rate. The capital rate is the sum of plant depreciation (scrap value being $10 \%$ of the total capital cost), property taxes of $1.4 \%$, insurance of $0.6 \%$, maintenance and repair of $3 \%$, a remuneration of $2.5 \%$, and a general charge of $1 \%$. A plant construction fee was excluded as it is less than $10 \%$ of the capital cost. The variable cost is the sum of a raw material fee, a utility fee, and a labor fee. A plant life of 10 


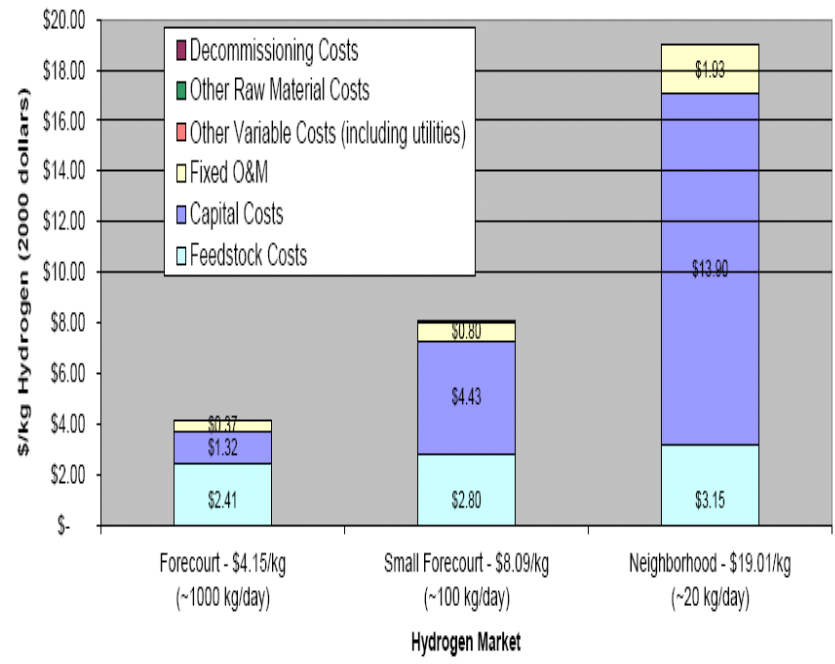

Figure 1. Hydrogen cost for Large, medium, and small markets [5].

years was assumed. However, it should also be noted that Hitachi based their S.-I. process costs on a General Atomic report, Brown et al. [7], using an exchange rate of $110 \mathrm{Yen} / \$$.

In Japan, the power generation cost for light water reactors is $5.9 \mathrm{Yen} / \mathrm{kWh}_{\mathrm{e}}$. Thus, for a thermal efficiency of $34 \%$, the heat cost is $\sim 2 \mathrm{Yen} / \mathrm{kWh}_{\mathrm{t}}$. The hydrogen production cost from such a plant was $\$ 1.30 / \mathrm{kg}$ in 2004 currency. Table 1 shows that for the S.-I. process cost to be competitive with that of the steam-methane reforming, the thermal efficiency has to be above $50 \%$ and the thermal power of the nuclear reactor has to be $\sim 3000 \mathrm{MW}_{\mathrm{t}}$.

Table 2 shows the cost of the hydrogen generation by a PEM electrolysis system. Power needed in the electrolysis system was $4.3 \mathrm{kWh} / \mathrm{nm}^{3}(47.95 \mathrm{kWh} / \mathrm{kg})$. Karasawa [6] concluded that a thermal power of $>600 \mathrm{MW}_{\mathrm{t}}$ and power cost of $<\$ 0.027 / \mathrm{kWh}$ are needed for the process to be competitive with the steam reforming process for hydrogen generation.

Table 1. Hydrogen production cost $(\$ / \mathrm{kg})$ for S.-I. process.

\begin{tabular}{|c|c|c|c|c|}
\hline \multirow{2}{*}{$\begin{array}{c}\text { Thermal } \\
\text { Power } \\
\text { (MWt) }\end{array}$} & \multicolumn{4}{|c|}{ Thermal Efficiency of S.-I. process } \\
\cline { 2 - 5 } & \multicolumn{3}{|c|}{$45 \%$} & \multicolumn{2}{c|}{$55 \%$} \\
\cline { 2 - 5 } & \multicolumn{3}{|c|}{ Heat Cost $(\$ \times 100 / \mathrm{kWh})$} \\
\cline { 2 - 5 } & 1.82 & 1.17 & 1.82 & 1.17 \\
\hline \multirow{3}{*}{15} & 5.04 & 4.47 & 4.51 & 4.04 \\
\hline 60 & 3.75 & 3.19 & 3.31 & 2.85 \\
\hline 300 & 2.87 & 2.30 & 2.48 & 2.02 \\
\hline 1000 & 2.46 & 1.90 & 2.11 & 1.64 \\
\hline 3000 & 2.22 & 1.65 & 1.88 & 1.41 \\
\hline
\end{tabular}

These studies concluded that for the new process to be competitive with the steam-methane reforming process, the thermal power has to be cheap and the plant size has to be large.

The present paper performs lifecycle cost analysis of the reference design for a commercial-scale high-temperature electrolysis (HTE) plant for hydrogen production. The primary advantage of HTE over conventional electrolysis is its higher efficiency, which is due to both the higher powercycle efficiency and electrolyzer efficiency associated with high-temperature operation. From thermodynamics, the electrical energy requirement for steam electrolysis decreases with increasing temperature, while the thermal energy requirement increases. Consequently, at higher temperatures, a larger fraction of the total electrolysis energy input can be supplied in the form of heat, increasing the overall process efficiency. In terms of electrochemical kinetics, activation and ohmic overpotentials also decrease dramatically with temperature. This combination of factors combined with power conversion efficiencies in excess of $50 \%$ for the hightemperature helium-cooled reactor operating at $900^{\circ} \mathrm{C}$ reactor outlet temperature (discussed later), also results in hydrogen production efficiencies greater than or comparable to other hydrogen production processes currently being developed, including high-temperature thermochemical hydrogen production processes [8].

UniSim process-analysis software, a derivative of the HYSYS software, was used in the optimization of the commercial-scale hydrogen production plant coupled to a high-temperature nuclear reactor. The optimized design described in this paper includes a nuclear reactor power source coupled to the Brayton power cycle and integrated with a HTE plant. The lifecycle cost analysis was performed using the H2A (Hydrogen Analysis) methodology developed by the DOE Hydrogen Program [9]. This methodology utilizes a spreadsheet analysis tool that requires detailed plant performance information, along with financial and cost information to calculate lifecycle costs for a specific set of

Table 2. Hydrogen production cost $(\$ / \mathrm{kg})$ for electrolysis method [6].

\begin{tabular}{|c|c|c|c|c|}
\hline \multirow{2}{*}{$\begin{array}{l}\text { Thermal } \\
\text { Power } \\
\text { (MWt) }\end{array}$} & \multicolumn{4}{|c|}{ Power Cost (\$x100/kWh) } \\
\cline { 2 - 5 } & 5.36 & 4.55 & 3.64 & 2.73 \\
\hline 15 & 3.48 & 3.08 & 2.65 & 2.21 \\
\hline 60 & 3.15 & 2.76 & 2.32 & 1.88 \\
\hline 300 & 2.92 & 2.52 & 2.09 & 1.65 \\
\hline 1000 & 2.81 & 2.42 & 1.98 & 1.54 \\
\hline 3000 & 2.74 & 2.35 & 1.91 & 1.48 \\
\hline
\end{tabular}


assumptions. These assumptions can be varied to perform sensitivity studies. The following sections discuss the reference INL HTE design concept along with operating conditions and performance parameters used to develop the lifecycle cost estimate.

\section{HELIUM RECUPERATED BRAYTON POWER CYCLE}

INL $[10,11]$ previously analyzed three advanced nuclear reactor-power cycle combinations, including: a hightemperature helium-cooled reactor coupled to a direct helium recuperated Brayton cycle, a supercritical $\mathrm{CO}_{2}$-cooled reactor coupled to a direct supercritical $\mathrm{CO}_{2}$ recompression cycle, and a sodium-cooled fast reactor coupled to a tertiary steam Rankine cycle. The three advanced nuclear reactor power cycle concepts were capable of operating with reactor outlet temperatures in the range of 550 to $900^{\circ} \mathrm{C}$. These high temperature reactor concepts result in higher power cycle efficiencies (33 to 55\%) than that of current generation light water reactors (30 to $35 \%$ ). In addition, the availability of high temperature process heat from these advanced reactors can further enhance hydrogen production efficiencies. Based on these results, a high-temperature gas-cooled nuclear reactor coupled to a helium recuperated Brayton power cycle (as shown in Figure 2 with $600 \mathrm{MW}_{\mathrm{t}}$ power and a power conversion efficiency of $53.2 \%$ ) was selected as the reference power source [12]. The primary helium coolant in Figure 2 exiting the reactor at $900^{\circ} \mathrm{C}$, is split at $\mathrm{T} 1$, with more than $85 \%$ of the flow going to the power cycle and the remainder $(\leq 15 \%)$ going to the intermediate heat exchanger (IHX) to provide process heat for the HTE loop. The cooler helium leaving the IHX (stream 3 in Figure 2) is then returned to the reactor at the inlet pressure and mixed with the primary

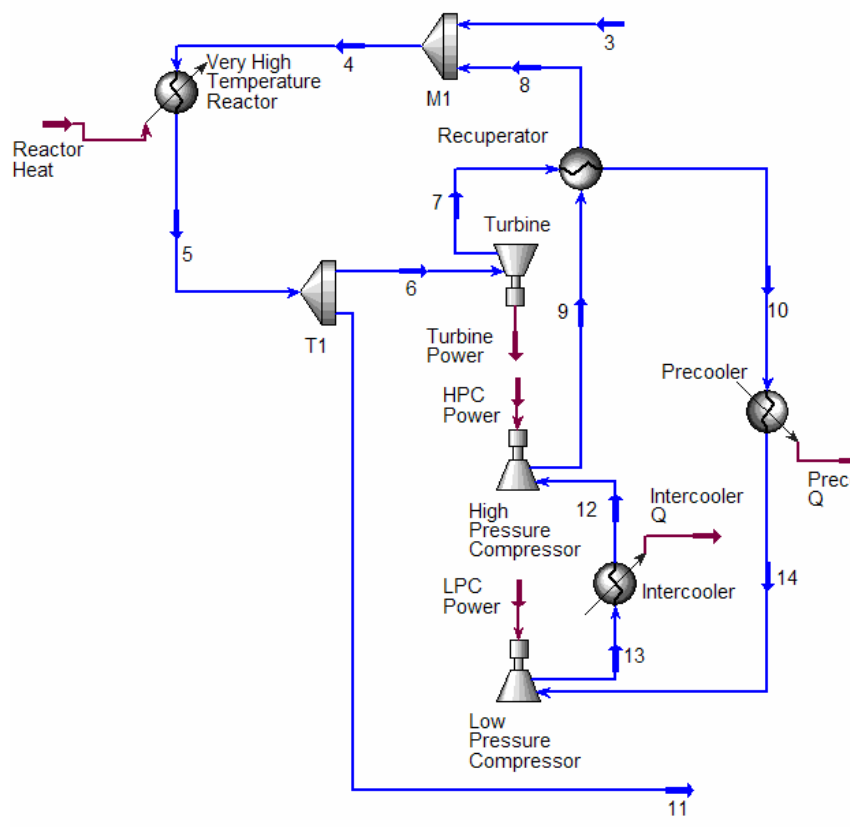

Figure 2. Process flow diagram for helium recuperated direct Brayton cycle. coolant returning to the reactor. The helium exits from the power turbine at a reduced pressure and temperature, and then passes through a recuperator and precooler where it is further cooled before entering the low-pressure compressor. To improve compression efficiency, the helium is again cooled in an intercooler before entering the high-pressure compressor. The helium exits the high-pressure compressor at a pressure that is slightly higher than the reactor operating pressure of $7 \mathrm{MPa}$. The coolant then circulates back through the recuperator where the recovered heat raises its temperature to the reactor inlet temperature of $540^{\circ} \mathrm{C}$, completing the cycle.

\section{HIGH TEMPERATURE ELECTROLYSIS PROCESS}

Various concepts of coupling nuclear reactors with the HTE hydrogen production plant were evaluated $[10,11]$. These concepts included operating the HTE plant at pressures of 3.5 and $7.0 \mathrm{MPa}$, and with and without the use of sweep gas to remove the excess oxygen from the anode side of the electrolyzer. These studies optimized hydrogen production rates and efficiencies using various operating parameters for several plant components. Based on the results of these parametric studies, an air-sweep system was selected for the reference design. While slightly higher overall hydrogen production efficiencies (an increase of $1.0-1.5 \%$ ) can be achieved when no gas sweep system is used, concerns with the handling of the high temperature oxygen product gas led to the decision to use an air-sweep system for oxygen removal from the electrolyzer anode [12].

The operating pressure of the HTE plant was also evaluated. A higher operating pressure yields pressurized hydrogen, which result in smaller components and lower system pressure drops for a given mass flow rate, but lower overall hydrogen production efficiency. Based on these consideration and analyses performed at system operating pressures of 3.5 and $7.0 \mathrm{MPa}$, an operating pressure of 5.0 $\mathrm{MPa}$ was selected for the reference design. The decision to operate at $5.0 \mathrm{MPa}$ was also influenced by the need to deliver the hydrogen gas at elevated pressure for storage or pipeline transport. Therefore, for this application, it is logical to compress the liquid water feedstock at the process inlet since liquid-phase compression work is very small compared to compression of the gaseous product.

Based on the above considerations, a discussion of the coupled high temperature nuclear reactor and HTE hydrogen production plant design developed by the INL and used in the $\mathrm{H} 2 \mathrm{~A}$ lifecycle cost analysis is provided in the following section.

\section{COUPLED REACTOR POWER CYCLE AND THE HIGH TEMPERATURE ELECTROLYSIS PLANT}

The overall process flow diagram for the hightemperature helium-cooled reactor coupled to the direct helium Brayton power cycle and the HTE plant with air sweep is presented in Figure 3. The inlet liquid water feedstock at $15.6^{\circ} \mathrm{C}$ is pressurized to the process pressure of 5.0 MPa. Downstream of the pump, condensate from the 


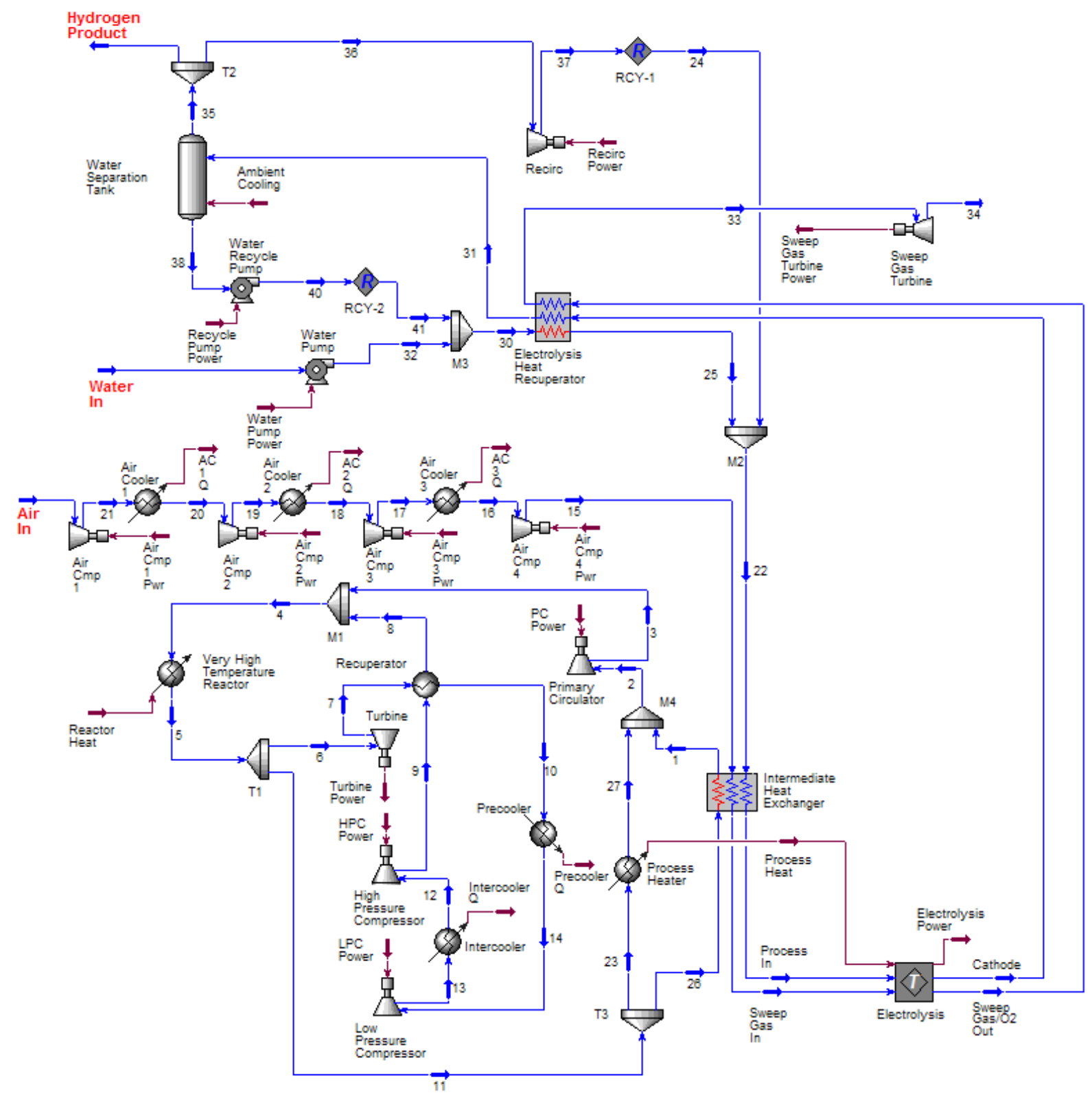

Figure 3. Process flow diagram for helium-cooled reactor/direct Brayton/HTE system with air sweep.

water knockout tank is recycled back into the inlet stream at M3. The water stream is then vaporized and pre-heated in the electrolysis recuperator, which recovers heat from the electrolyzer output streams.

Downstream of the electrolysis heat recuperator, at M2, the steam is mixed with recycled hydrogen product gas to maintain reducing conditions on the steam-hydrogen electrode. The inlet steam-hydrogen $(90-10 \%$ by volume $)$ mixture is heated in the IHX to the electrolysis operating temperature using high-temperature process heat from the nuclear reactor. The steam-hydrogen mixture then enters the solid oxide electrolysis cell (SOEC) stack, where oxygen is electrolytically removed from the steam, producing hydrogen and oxygen. An additional process heater is also used to add heat from the reactor primary system to the electrolysis process to maintain the electrolyzer operating conditions at $800^{\circ} \mathrm{C}$. Downstream of the electrolyzer, the hydrogen-rich product stream flows through the electrolysis recuperator where the product stream is cooled and the inlet process stream is preheated. The product stream is cooled further at the water separation tank, where the residual steam is condensed, yielding dry hydrogen product. The cooled product stream is split at $\mathrm{T} 2$ and a fraction of the product hydrogen is recycled into the inlet process stream, as discussed previously. A recirculating blower is required to repressurize the recycle stream to the upstream pressure at M2.

The process flow diagram shows air being used as a sweep gas to remove the excess oxygen that is evolved on the anode side of the electrolyzer. The inlet sweep air is compressed to the system operating pressure of 5.0 MPa in a four-stage compressor with intercooling. After exiting from 
the final compression stage, the air enters the IHX at about $171^{\circ} \mathrm{C}$ and is heated to the electrolyzer operating temperature of $800^{\circ} \mathrm{C}$ using heat obtained directly from the nuclear reactor. The sweep air then enters the electrolyzer and exits mixed with additional oxygen. Finally, it passes through the electrolysis recuperator to preheat the incoming inlet gas. Some of the sweep air compression work is recovered by expanding it in a sweep-air turbine.

The INL developed an integral electrolyzer model for direct incorporation into the UniSim system analysis code [13]. This electrolysis model for UniSim calculates the electrolyzer heat requirements. An embedded spreadsheet is used to calculate the Nernst potential, operating voltage, current and electrolysis power based on the integral electrolyzer model.

\section{ECONOMIC ANALYSIS OF A REFERENCE DESIGN}

As noted earlier, the H2A economic analysis methodology developed by the DOE requires detailed information on plant design and performance in order to calculate lifecycle cost. Therefore, basic information was collected on stream composition, flow rates, temperatures, pressure, thermal duty, heat rates, heat transfer coefficients, component design, and performance information at each of the locations shown in Figure 3 and are used for input to the $\mathrm{H} 2 \mathrm{~A}$ lifecycle cost analysis. All of this information is provided in detail in [14].

Development of the H2A methodology was initiated in February 2003 to improve the transparency and consistency of the analysis approach, to improve the understanding of the differences among analyses, and to seek better validation of analysis studies by industry. The first task of the H2A effort was to develop a standardized approach and set of assumptions for estimating the costs of hydrogen production and delivery technologies. Applying the same methodology to each production and delivery technology, will lead to an equitable comparison across various options.

The standardized approach and set of assumptions for estimating the lifecycle cost of hydrogen production was incorporated into a spreadsheet and used for the economic analyses of the INL reference HTE design. This standardized spreadsheet provides a method of documenting information utilized in the performance of the economic analyses. The information incorporated in the spreadsheet and given in the INL report [14] includes:

- Original source(s) of all the data

- Feedstock and energy inputs, plant size, co-products, etc.

- Process flowsheet and flow stream data (flow-rate, temperature, pressure, composition of each stream, etc.).

- Process efficiency and hydrogen product conditions.

- Economic assumptions (after-tax rate of return, depreciation schedule, plant lifetime, income tax rate, capacity factor, etc.).

- Calculation of the discounted cash flow (all technologies use the same methodology to calculate cash flow).
- Plant-gate $\mathrm{H}_{2}$ selling price, cost components in $\$ / \mathrm{kg}$, operating efficiency, total fuel and feedstock consumption, and emissions.

- Sensitivity of the $\$ / \mathrm{kg}$ cost to feedstock cost, co-product selling price, capital cost, operating cost, internal rate of return, conversion efficiencies, etc.

- Quantification of the level of uncertainty in the analysis.

The results of lifecycle costing exercises depend on various financial assumptions. To facilitate a common basis for comparing alternative hydrogen production technologies, a standard set of assumptions were developed. These assumptions are delineated in the following section.

\section{ASSUMPTIONS}

A set of common cost assumptions was incorporated into the $\mathrm{H} 2 \mathrm{~A}$ economic analysis spreadsheet. These assumptions can be varied to test the sensitivity of costs to the most critical assumptions. The set of base case assumptions used in the H2A methodology are [9]:

- Analysis Methodology - Discounted Cash Flow (DCF) model that calculates a levelized $\mathrm{H}_{2}$ price that yields a prescribed Internal Rate of Return (IRR)

- Reference Financial Structure - 100\% equity with $10 \%$ IRR - include levelized $\mathrm{H}_{2}$ price plot for 0 to $25 \%$ IRR - model allows debt financing

- Reference Year Dollars - 2005, to be adjusted at half-decade increments (e.g., 2005, 2010)

- Technology Development Stage - All Central and Forecourt cost estimates are based on mature, commercial facilities

- Inflation Rate - $1.9 \%$, but with resultant price of $\mathrm{H}_{2}$ in reference year constant dollars

- Income Taxes - 35\% Federal, 6\% State; 38.9\% Property Taxes; Insurance - 2\%/year of the total initial capital cost

- Sales Tax - Not included because facilities and related purchases are wholesale and through a general contractor entity

- Working Capital Rate - $15 \%$ of the annual change in the total operating costs

- Analysis Period - 40 years for Central; 20 years for Forecourt

- Facility Life - 40 years for Central with case exceptions; 20 years for Forecourt with case exceptions

- Depreciation Type and Schedule for Initial Depreciable Capital Cost - Modified Accelerated Cost Recovery System (MACRS), 20 years for Central with case exceptions; 7 years for Forecourt

- Construction Period and Cash Flow - Variable for Central; 0 for Forecourt

- Planned Replacement Capital - Post-startup capital costs spread over time based on specific replacement estimates. Depreciation is based on MACRS schedule and 7 years or same as the replacement period if it is shorter than 7 years.

- Unplanned Replacement Capital - Specified percentage of initial depreciable capital cost for unplanned replacement 
capital expenses occurring during a year. Depreciation is based on MACRS schedule and 7 years.

- Project Contingency - \% adjustment to the total initial capital cost to represent the mean or expected cost value. Periodic replacement capital includes project contingency.

- Process Contingency - \% adjustment to the total initial capital cost to represent the mean or expected overall performance.

- Land Cost - \$5000/acre purchased for Central; \$0.50/sq.ft. per month for long-term lease for Forecourt

- Capacity Factor - 90\% for Central, with case exceptions; $70 \%$ for Forecourt

- Average Burdened Labor Rate for Staff - \$50/hour for Central; $\$ 15 /$ hour for Forecourt

- General and Administrative (G\&A) Rate - $20 \%$ of the staff labor costs above

- Forecourt Maintenance - 5\%/yr of initial depreciable capital cost for small capacity and 3\%/yr for large capacity

- Co-produced and Co-generated Electricity Price - $\$ 30 / \mathrm{MWh}$ with sensitivities (\$20/MWh low and \$50/MWh high)

- $\mathrm{CO}_{2}$ incentive (when $\mathrm{CO}_{2}$ sequestration is not plausible) not included in Base cases, sensitivity included at $\$ 100 /$ tonne $\mathrm{C}\left(\$ 27.3 /\right.$ tonne $\left.\mathrm{CO}_{2}\right)$ for Central and Forecourt.

- $\mathrm{O}_{2}$ Credit - Not included in Base cases, sensitivity included at \$20/tonne for Central and Forecourt.

- Salvage Value - $10 \%$ of initial capital, with case exceptions; $0 \%$ for Forecourt

- Decommissioning - $10 \%$ of initial capital, with case exceptions; 0\% for Forecourt

- Hydrogen Pressure at Central Gate - 2.17 MPa (300 psig). If delivered at higher pressure, take credit for pressure $>2.17$ MPa.

- Central Storage - Buffer only as required for efficient operations

- Hydrogen Storage Pressure at Forecourt - 43.19 MPa (6250 psig)

- Forecourt Compressed $\mathrm{H}_{2}$ Storage - $87.5 \%$ of maximum daily production (based on $35 \%$ of production divided by an assumed $40 \%$ dispensable hydrogen fraction)

- Hydrogen Purity - $>98 \%$; $\mathrm{CO}<10 \mathrm{ppm}$, sulfur $<10 \mathrm{ppm}$

- Sensitivity Variables and Ranges - Based on applying best judgment of $10 \%$ and $90 \%$ confidence limit extremes to the most significant baseline cost and performance parameters

The above assumptions along with basic process information calculated using the UniSim model shown in Figure 3 were input to the $\mathrm{H} 2 \mathrm{~A}$ spreadsheet to calculate the lifecycle cost for the hydrogen production process. The input to the spreadsheet and calculated lifecycle costs are described in more detail in the next two sections.

\section{INPUT TO H2A LIFECYCLE ANALYSIS}

Input for the $\mathrm{H} 2 \mathrm{~A}$ lifecycle cost analysis for the reference HTE design included plant performance and process information obtained from the UniSim model of the reference HTE design. Financial data, and cost information (including capital, operating, maintenance, variable production, and replacement costs) were primarily based on the assumptions described earlier, but many of these values can also be changed by the user to perform sensitivities on the important financial assumptions. Plant-specific financial input by the user includes information on the construction time, plant startup date, plant design production capacity, plant operating capacity factor, capital expenditure rate during construction, and revenue and operating costs during startup. Most of the financial input uses the recommended guidelines of the H2A methodology [15]. Construction costs were assumed to be evenly distributed over a 3 year construction period. The 1 year startup period and the startup revenues and costs (fixed and variable) were estimated by the INL. The plant salvage value and decommissioning costs are taken per the assumptions of the $\mathrm{H} 2 \mathrm{~A}$ analysis methodology. Plant capital cost includes uninstalled and installed system and equipment costs, indirect depreciable capital costs (including site preparation, engineering and design, licensing and permitting, and associated contingencies), and nondepreciable capital costs (primarily the cost of the plant land). Plant equipment costs include equipment costs for both the nuclear and the hydrogen production plant. The nuclear equipment costs are based on estimates developed by General Atomics for a pre-conceptual design [16]. For the nuclear equipment, an installation multiplier (the ratio of installed and uninstalled costs) of 1.35 was used based on the General Atomics pre-conceptual design report. For the hydrogen production plant equipment, installation factors are based on the various equipment references [17-19]. The total installed cost of plant equipment is $\$ 469,159,854$. This represents the total depreciable direct capital investment.

The total indirect depreciable capital costs (engineering and design, contingencies and licensing/permitting fees) amount to $\$ 203,338,738$. Adding these costs to the direct depreciable costs, gives a total depreciable capital cost for the reference HTE plant of $\$ 672,498,592$. The only nondepreciable cost assumed in the reference plant lifecycle analysis was the cost of land required for the plant site. The land required for the plant (including the exclusion area) was assumed to be 200 acres. At an assumed cost of $\$ 5000$ per acre ( $\mathrm{H} 2 \mathrm{~A}$ guideline), the total non-depreciable land cost is $\$ 1,000,000$. Adding this cost to the total direct and indirect depreciable capital costs gives a total capital investment cost for the reference HTE plant of $\$ 673,498,592$. Additional costs to be considered in the reference HTE plant lifecycle analysis are the operation and maintenance (O\&M) costs and variable production costs. The operations and maintenance costs include burdened labor and material costs, various plant permits, licenses, fees and taxes.

These total fixed O\&M costs amount to $\$ 36,827,633 / \mathrm{yr}$. The variable production costs include the cost of the nuclear fuel $(\$ 17,800,000$ per year) and demineralized water $(\$ 790,888)$, which is the feedstock for the electrolyzer. Adding these variable costs to the fixed O\&M costs give a total fixed and variable yearly O\&M cost of $\$ 55,418,521$.

The only remaining costs to be considered in the reference HTE plant lifecycle analysis are the planned and 
unplanned yearly replacement costs. The planned replacement costs are the yearly cost of replacement of $1 / 3$ of the Solid Oxide Electrolyzer (SOE) modules, which amounts to $\$ 17,186,667 / y r$. In the lifecycle analysis, unplanned replacement costs were assumed to be $2.0 \%$ of total depreciable costs per year, and amount to $\$ 13,449,972$.

The financial and cost information described above provided the input for the $\mathrm{H} 2 \mathrm{~A}$ lifecycle spreadsheet analysis of the reference HTE hydrogen production plant. Tables 3 and 4 summarize the capital investment and operational cost information developed for the reference HTE plant.

\section{RESULTS OF H2A LIFECYCLE ANALYSIS}

The results of the H2A lifecycle cost analysis include a cash flow analysis for the plant construction and startup periods, and for the operating life of the plant. The required hydrogen cost (price) in 2005 dollars is also determined based on the plant hydrogen-production capacity and assuming an after-tax internal rate of return (IRR) of $10 \%$. A critical assumption in this analysis is the assumed reactor outlet temperature. A reactor outlet temperature of $900^{\circ} \mathrm{C}$ rather than $950^{\circ} \mathrm{C}$ was chosen for the reference HTE plant design because the lower temperature is more consistent with the operating temperature range of currently available materials and components. This reactor outlet temperature, along with the details of the power cycle and electrolyzer yields an overall hydrogen production efficiency of $47.1 \%$.

To achieve an after tax internal rate of return of $10 \%$ the required hydrogen price calculated using the $\mathrm{H} 2 \mathrm{~A}$ spreadsheet methodology is $\$ 3.23 / \mathrm{kg}$. This represents the price or cost of the hydrogen leaving the plant gate at $5 \mathrm{MPa}$ pressure, and does not include any additional storage, delivery, fuel taxes or other costs that the consumer might pay at the pump. The breakdown of these costs showing the different cost contributions is shown in Table 5.

As expected, capital costs $\left(\$ 2.36 / \mathrm{kg} \mathrm{H}_{2}\right)$ represent the largest contribution to the total hydrogen cost because of the high construction costs for the nuclear reactor. In this case, nuclear plant capital costs represent about $70 \%$ of the total capital cost, or approximately $\$ 1.65 / \mathrm{kg}$ of hydrogen. Fixed operation and maintenance costs $(\$ 0.57 / \mathrm{kg}$ of hydrogen) are relatively high $(\sim 18 \%)$ because they include operation and maintenance costs for both the reactor and the hydrogen production plant. The variable costs $(\$ 0.28 / \mathrm{kg}$ of hydrogen $)$ contribute about $8.7 \%$ and include the nuclear reactor fuel cost, a reserve for replacement costs of unplanned equipment, the SOE cells, decommissioning, and raw material costs. The cost of the SOE modules was estimated to be $\$ 200 / \mathrm{kW}$ of power to the electrolysis stack and, as noted earlier, it is assumed that $1 / 3$ of the modules are replaced each year. The unplanned replacement costs were assumed to be $2 \%$ of the total direct depreciation costs per year. Since the reactor power source provided both electricity and process heat to drive the hydrogen production process, there are no utility or raw material cost contributions to the total hydrogen production cost. The feedstock cost contribution $(\$ 0.012 / \mathrm{kg}$ of hydrogen) represents the cost of the demineralized water
Table 3. Summary of capital investment costs ( $2005 \$$ ).

\begin{tabular}{|l|c|}
\hline \multicolumn{1}{|c|}{ Capital Cost Items } & Cost, \$ \\
\hline $\begin{array}{l}\text { Direct depreciable costs (equipment } \\
\text { and systems) }\end{array}$ & $469,159,854$ \\
\hline $\begin{array}{l}\text { Indirect depreciable costs (site prep., } \\
\text { engineering, permitting) }\end{array}$ & $203,338,738$ \\
\hline $\begin{array}{l}\text { Total direct and indirect } \\
\text { depreciable cost }\end{array}$ & $\mathbf{6 7 2 , 4 9 8 , 5 9 2}$ \\
\hline Non-depreciable cost (land) & $1,000,000$ \\
\hline Total capital investment cost & $\mathbf{6 7 3 , 4 9 8 , 5 9 2}$ \\
\hline
\end{tabular}

Table 4. Summary of operating costs ( $2005 \$$ ).

\begin{tabular}{|l|c|}
\hline \multicolumn{1}{|c|}{$\begin{array}{c}\text { O\&M, Variable and Replacement } \\
\text { Cost Items }\end{array}$} & Cost, \$/yr. \\
\hline $\begin{array}{l}\text { Fixed O\&M costs (staff, taxes, } \\
\text { permitting) }\end{array}$ & $36,827,633$ \\
\hline $\begin{array}{l}\text { Variable production costs (nuclear } \\
\text { fuel and feedwater stock) }\end{array}$ & $18,590,888$ \\
\hline $\begin{array}{l}\text { Replacement costs (SOE modules and } \\
\text { unplanned replacements) }\end{array}$ & $30,636,639$ \\
\hline \multicolumn{1}{|c|}{ Total yearly costs } & $\mathbf{8 6 , 0 5 5 , 1 6 0}$ \\
\hline
\end{tabular}

feedstock, which feeds the electrolysis process. Although the electrolysis process also produces oxygen, which could be sold as a byproduct of the hydrogen production process, the reference HTE design does not attempt to recover the oxygen byproduct. Therefore, while the sale of the oxygen byproduct would lower the overall cost of the hydrogen production process by about $\$ 0.17 / \mathrm{kg}$, no credit for the production of oxygen was taken in this cost analysis.

Figure 4 is a plot of the calculated cash flow for the reference HTE design for a calculated design hydrogen production rate of $2.356 \mathrm{~kg} / \mathrm{s}$, an operating capacity factor of $90 \%$, and an operating life of 40 years. The equivalent yearly hydrogen production rate for the plant for these conditions is $66,870,251 \mathrm{~kg} / \mathrm{yr}$. Figure 4 shows that the initial capital investment is recovered approximately 8 years after the start

Table 5. Hydrogen cost and cost contributions (2005 \$)

\begin{tabular}{|l|c|}
\hline $\begin{array}{l}\text { Hydrogen Cost } \\
\left(\text { Year 2005 } \mathbf{\$} \mathbf{k g} \text { of } \mathbf{H}_{2}\right)\end{array}$ & $\mathbf{\$ 3 . 2 2 9}$ \\
\hline Capital Cost Contribution $\left(\$ / \mathrm{kg}\right.$ of $\left.\mathrm{H}_{2}\right)$ & $\$ 2.364$ \\
\hline $\begin{array}{l}\text { Decommissioning Cost Contribution } \\
\left(\$ / \mathrm{kg} \text { of } \mathrm{H}_{2}\right)\end{array}$ & $\$ 0.002$ \\
\hline $\begin{array}{l}\text { Fixed O\&M Cost Contribution } \\
\left(\$ / \mathrm{kg} \text { of } \mathrm{H}_{2}\right)\end{array}$ & $\$ 0.573$ \\
\hline $\begin{array}{l}\text { Feedstock Cost Contribution } \\
\left(\$ / \mathrm{kg} \text { of } \mathrm{H}_{2}\right)\end{array}$ & $\$ 0.012$ \\
\hline $\begin{array}{l}\text { Other Raw Material Cost Contribution } \\
\left(\$ / \mathrm{kg} \text { of } \mathrm{H}_{2}\right)\end{array}$ & $\$ 0.000$ \\
\hline $\begin{array}{l}\text { Byproduct Credit Cost Contribution }(\$ / \mathrm{kg} \\
\left.\text { of } \mathrm{H}_{2}\right)\end{array}$ & $\$ 0.000$ \\
\hline $\begin{array}{l}\text { Other Variable Costs }(\text { including utilities) } \\
\text { Contribution }\left(\$ / \mathrm{kg} \text { of } \mathrm{H}_{2}\right)\end{array}$ & $\$ 0.278$ \\
\hline Total O\&M $\left(\$ / \mathrm{kg}\right.$ of $\left.\mathrm{H}_{2}\right)$ & $\$ 0.863$ \\
\hline
\end{tabular}


Cumulative Cash Flow

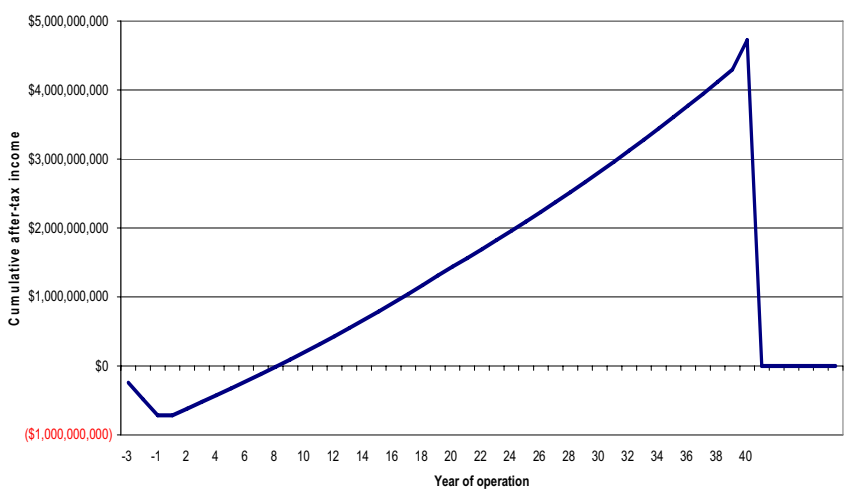

Figure 4. Cumulative cash flow for reference HTE plant.

of operation and the cumulative after-tax income over the life of the plant of slightly less than $\$ 5$ billion.

\section{SENSITIVITY STUDIES}

Several sensitivity analyses were performed to evaluate the impact of various economic assumptions on hydrogen lifecycle production costs. The assumed after-tax internal rate of return was found to have a significant impact on the cost of hydrogen production. Figure 5 shows that a variation of the internal rate of return from 0 to $25 \%$ results in hydrogen production cost variations between $\$ 1.64 / \mathrm{kg}$ of $\mathrm{H}_{2}$ and $\$ 7.40 / \mathrm{kg}$ of $\mathrm{H}_{2}$, respectively. Figure 6 is a tornado plot that shows the sensitivity of hydrogen production costs to the various economic and operational assumptions used in the $\mathrm{H} 2 \mathrm{~A}$ economic analysis of the reference HTE plant. The tornado plot shows the impact on hydrogen production cost when a single variable is changed while holding other variables constant at their base case values. In the tornado plot, the parameters that have the largest impact on production costs are shown at the top, and the parameters that have the least impact on hydrogen production costs are shown at the bottom. Therefore, the importance of parameters on hydrogen production costs decreases as the plot is read from top to bottom. As indicated in the plot, the after-tax internal rate of return has the greatest impact on hydrogen production costs. Unplanned replacement costs are next in importance. In this analysis, unplanned replacement costs were assumed to be $2 \%$ of the total direct depreciation costs per year. When the unplanned replacement costs are varied from 0 to $10 \%$, the resulting hydrogen production costs vary between $\$ 2.94 / \mathrm{kg}$ and $\$ 4.39 / \mathrm{kg}$, respectively. The third most important parameter in the cost analyses is the assumed cost of the SOE modules. In this analysis, the cost of the SOE modules was assumed to be $\$ 200$ per $\mathrm{kW}$ of electricity to the electrolysis stack. If this cost is varied between $\$ 100$ and $\$ 300 / \mathrm{kW}$, the corresponding cost of hydrogen varies from $\$ 2.83$ to $\$ 3.63 / \mathrm{kg}$, respectively. Variations in the size of the plant staff, the cost of major reactor system components and the frequency at which the SOE cells are replaced, all appear to have moderate affects on the cost of hydrogen production. Variations in engineering design costs seem to have only a small impact on hydrogen

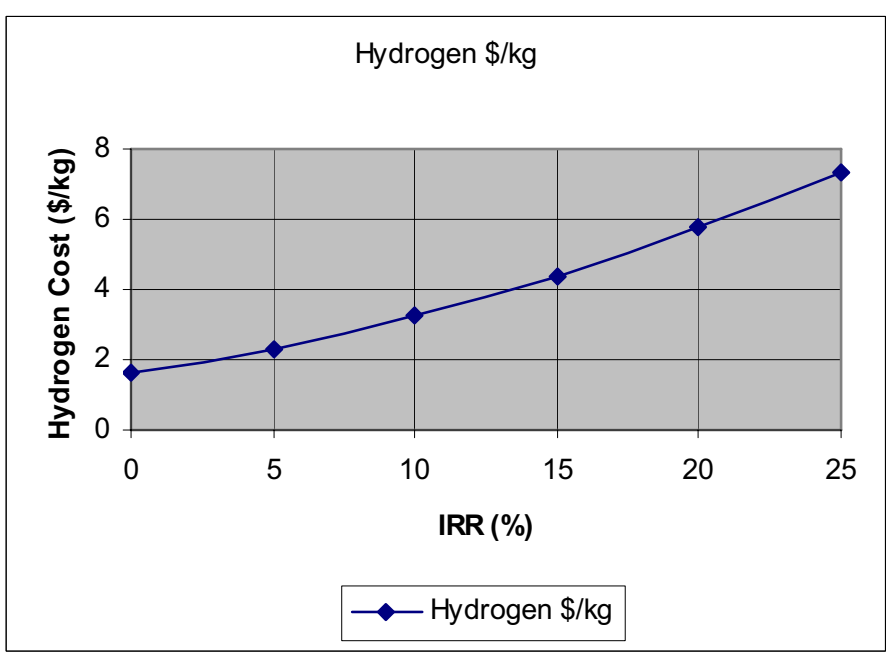

Figure 5. Calculated hydrogen production cost as a function on internal rate of return.

production cost. Because the cost of the hydrogen plant equipment (turbomachinery, heat exchangers, piping, etc.) is low compared to the cost of the nuclear plant equipment and the SOE modules, the impact of variations in major hydrogen plant equipment costs has the least impact on hydrogen production costs of the parameters considered.

\section{CONCLUSIONS}

This paper presents results of a lifecycle cost analysis of the optimized design for a reference commercial-scale hightemperature electrolysis (HTE) plant for hydrogen production. The reference HTE plant is driven by a $600 \mathrm{MW}_{\mathrm{t}}$ high-temperature helium-cooled reactor coupled to a direct Brayton power cycle with a reactor outlet temperature of $900^{\circ} \mathrm{C}$. Plant parameters used in the reference plant optimization are based on previous parametric studies performed using the UniSim process analysis software [10, 11]. Based on the standardized H2A analysis methodology, and the various assumptions discussed in this paper, the estimated price of the hydrogen leaving the plant gate at 5 $\mathrm{MPa}$ pressure would be $\$ 3.23 / \mathrm{kg}$. This estimated price is most sensitive to the assumed after-tax internal rate of return and the cost of unplanned replacement costs. Compared to the current hydrogen commodity price of about $\$ 2.50 / \mathrm{kg}$ (based on steam-methane reforming), this estimated cost is not unreasonable considering the volatility of the cost of the natural gas and the fact that the HTE technology does not emit greenhouse gases.

Isothermal operation of the electrolyzer was assumed. An air sweep system is also included in the reference design to remove oxygen from the anode side of the electrolyzer because of concerns with handling of the high-temperature oxygen product gas. Predicted overall thermal-to-hydrogen efficiency values for the reference design with an air-sweep system resulted in hydrogen production efficiencies that were only $1.0-1.5 \%$ lower than that for the equivalent design with no sweep-gas system [10]. The operating pressure of 5.0 $\mathrm{MPa}$ for the HTE process loop was selected to be consistent 


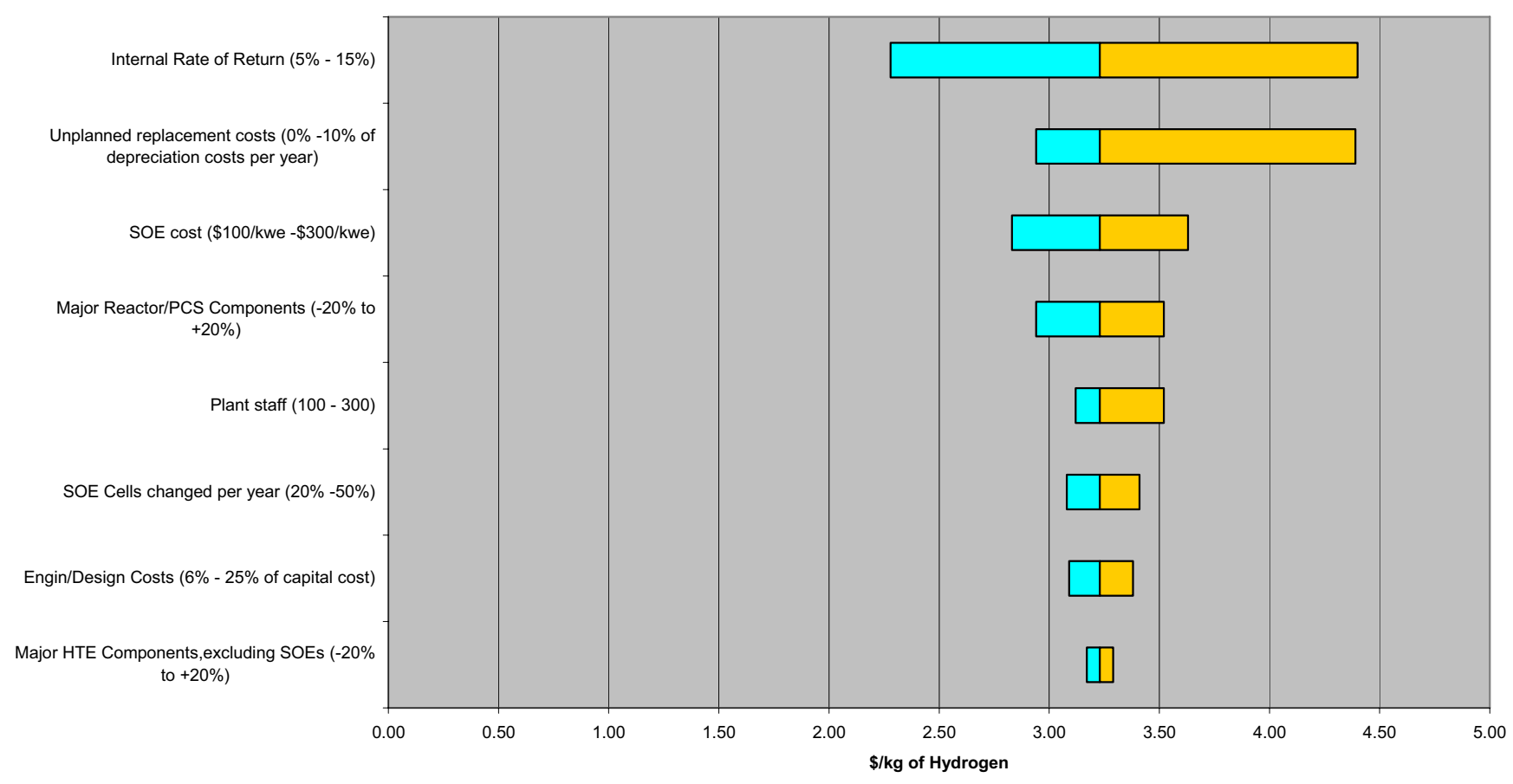

Figure 6. Tornado plot showing sensitivity of hydrogen cost to parameter variations.

with the need to deliver the hydrogen product gas at elevated pressures for storage or pipeline transport. This pressure also represents a trade off between the need for larger components at lower pressures and the need for more massive components for pressure containment at higher pressures. The overall thermal-to-hydrogen efficiency for the reference case is $47.1 \%$.

The lifecycle cost analysis of the reference HTE design resulted in a calculated hydrogen cost of $\$ 3.23 / \mathrm{kg}$, assuming an after-tax internal rate of return of $10 \%$. This represents the cost of hydrogen leaving the plant gate, and does not include any additional storage, delivery, fuel taxes or other costs that the consumer might pay at the pump. A breakdown of the component costs contributing to the total cost of $\$ 3.23 / \mathrm{kg}$ shows that capital costs account for over $70 \%$ of total costs (i.e., $\$ 2.36 / \mathrm{kg}$ of $\mathrm{H}_{2}$ ). This is expected because of the high construction costs for the nuclear reactor. Fixed operating and maintenance costs $\left(\$ 0.57 / \mathrm{kg}\right.$ of $\left.\mathrm{H}_{2}\right)$ are relatively high because they include operation and maintenance costs for both the reactor and hydrogen production plant. Yearly variable costs $\left(\$ 0.28 / \mathrm{kg}\right.$ of $\left.\mathrm{H}_{2}\right)$ include the reactor fuel cost, a reserve for unplanned equipment replacement costs, and the yearly replacement cost of the solid oxide electrolysis cells. The cost of the SOEC modules was estimated to be $\$ 200 / \mathrm{kW}$ of power to the electrolysis stack and it is assumed that $1 / 3$ of the modules are replaced annually. The feedstock cost contribution $\left(\$ 0.012 / \mathrm{kg}\right.$ of $\left.\mathrm{H}_{2}\right)$ represents the cost of the demineralized water feedstock, which feeds the electrolysis process. Although the electrolysis process also produces oxygen, which could be sold as a byproduct of the hydrogen production process, the reference HTE design does not attempt to recover the oxygen byproduct. Therefore, while the sale of the oxygen byproduct would lower the overall cost of the hydrogen production process, no credit for the production of oxygen was taken in this cost analysis.

The information presented in this paper is intended to provide baseline hydrogen production costs for the optimized reference nuclear-driven HTE hydrogen production plant so that operating parameters and costs can be compared with other hydrogen production methods and power cycles to evaluate relative performance characteristics and plant economics.

\section{ACKNOWLEDGMENTS}

This work was supported by the Idaho National Laboratory, Laboratory Directed Research and Development program and by the U.S. Department of Energy, Office of Nuclear Energy, Nuclear Hydrogen Initiative Program.

\section{COPYRIGHT STATEMENT}

This manuscript has been authored by Battelle Energy Alliance, LLC under Contract No. DE-AC07-05ID14517 with the U.S. Department of Energy. The United States Government retains and the publisher, by accepting the article for publication, acknowledges that the United States Government retains a nonexclusive, paid-up, irrevocable, world-wide license to publish or reproduce the published form of this manuscript, or allow others to do so, for United States Government purposes.

\section{REFERENCES}

[1] O'Brien, J. E., Stoots, C. M., Herring, J. S., and Hartvigsen, J. J.,"Hydrogen Production Performance of a 10- 
Cell Planar Solid-Oxide Electrolysis Stack," Journal of Fuel Cell Science and Technology, Vol. 3, May 2006, pp. 213-219.

[2] O'Brien, J. E., Stoots, C. M., Herring, J. S., and Hartvigsen, J. J., "Performance of Planar High-Temperature Electrolysis Stacks for Hydrogen Production from Nuclear Energy," Nuclear Technology, Vol. 158, May 2007, pp. 118 131.

[3] Hawkes, G. L., O’Brien, J. E., Stoots, C. M., Herring, J. S., "CFD Model of a Planar Solid Oxide Electrolysis Cell for Hydrogen Production from Nuclear Energy," Nuclear Technology, Vol. 158, May 2007, pp. 132 - 144.

[4] Herring, J. S., O’Brien, J. E., Stoots, C. M., and Hawkes, G. L., "Progress in High-Temperature Electrolysis for Hydrogen Production using Planar SOFC Technology," International Journal of Hydrogen Energy, Vol. 32, No. 4, March 2007, pp. 440-450,

[5] Ivy, J., "Summary of Electrolytic Hydrogen Production," NREL Report NREL/MP-560-36734, September 2004.

[6] Karasawa, H., "Cost evaluation for centralized hydrogen production," Progress in Nuclear Energy, Vol. 47, No. 1-4, 2005, pp. 512-518.

[7] Brown, L.C., Lentsch, R. D., Besenbruch, G. E., Schultz, K. R., and Funk, J. F., "Alternative flowsheets for the sulfuriodine thermochemical hydrogen cycle," GA Project 30171 Report GA-A24266, 2003.

[8] Richards, M. B., et.al, "G2-MHR Pre-Conceptual Design Report: SI-Based Plant”, General Atomics Project 30165 GAA25401, April 2006.

[9] U.S. DOE Hydrogen Program Website, DOE H2A Analysis,

http://www.hydrogen.energy.gov/h2a analysis.html.

[10] O'Brien, J. E., McKellar, M. G., , Herring, J. S., "Performance Predictions for Commercial-Scale HighTemperature Electrolysis Plants Coupled to Three Advanced Reactor Types", ANS International Congress on Advances in Nuclear Power Plants (ICAPP08), June 8-12, 2008, Anaheim, CA.

[11] Harvego, E. A., McKellar, M. G., O'Brien, J. E., and Herring, J. S., "Summary of Reactor-Coupled HTE Modeling Sensitivity Studies," INL Internal (DOE Milestone) Report, October 26, 2006.

[12] McKellar, M. G., O’Brien, J. E., Harvego, E. A., and Herring, J. S., "Optimized Flow-Sheet for a Reference Commercial-Scale Nuclear-Driven High Temperature Electrolysis Hydrogen Production Plant", DOE Milestone Report, November 14, 2007.
[13] O'Brien, J. E., Stoots, C. M., and Hawkes, G. L., "Comparison of a One-Dimensional Model of a HighTemperature Solid Oxide Electrolysis Stack with CFD and Experimental Results," Proceedings of 2005 ASME International Mechanical Engineering Congress and Exposition, Nov. 5-11, 2005, Orlando, FL.

[14] Harvego, E. A., McKellar, M. G., Sohal, M. S., O'Brien, J. E., and Herring, J. S., "Economic Analysis of the Reference Design for a Nuclear-Driven High-Temperature-Electrolysis Hydrogen Production Plant," INL External Report, INL/EXT/-08-13799, January 30, 2008.

[15] U.S. DOE, "H2A Central Hydrogen Production Model Users Guide," Version 1.0.10, July 2005.

[16] Richards, M. B., Shenoy, A. S., Harvego, E. A., McKellar, M. G., Peddicord, K. L., Reza, S.M.M., Coupey, J. P., "H2-MHR Pre-Conceptual Design Report: HTE-Based Plant," GA-A25402, April 2006.

[17] Ulrich, G. D., "A Guide to Chemical Engineering Process Design and Economics," John Wiley and Sons, Inc., 1984.

[18] Matches website (Equipment cost estimating), http://matche.com/EquipCost .

[19] Loh, H. P., Lyons, J., and White, C. W., "Process Equipment Cost Estimation," National Energy Technology Center Report DOE/NETL-2002/1169, January 2002. 